\title{
The Socio-Cultural Paradigm of Studies of State Authority
}

\author{
Valentin Yakovlevich Lyubashits ${ }^{1}$ \\ Alexey Yurievich Mamychev² \\ Andrey Yurievich Mordovtsev² \\ Maria Vladimirovna Vronskaya² \\ ${ }^{1}$ Southern Federal University \\ 2 Vladivostok State University of Economics and Service \\ Email: vodenko-kv@rambler.ru
}

Doi:10.5901/mjss.2015.v6n3s6p301

\begin{abstract}
The article analyzes the current state of research of the government. Are allocated and systematized the main directions of research strategies and knowledge of the political and legal phenomenon. The necessity of development of the scientific direction, implying a comprehensive analysis of the state power as pravokulturnogo phenomenon. It is shown that in modern society the most appropriate system is a comprehensive review of the state as a complex socio-political and pravokulturnoy system, and the study of legal and political phenomena is based on the independence and integrity of the national political and legal organization of society (in the unity of its temporal and spatial development). The authors offer a review of the government, in the specific historical and socio-political conditions in six interrelated dimensions: value-normative, structuralfunctional, institutional and normative, instrumental, technological, sociological and geopolitical.
\end{abstract}

Keywords: state authority, the political process, law, civilization, legal doctrine.

\section{Introduction}

Modern intellectual and practical struggle for the "civilizational breakthrough" Russia's legal and political systems, their introduction to the Western European tradition and, ultimately, the yield on the "high road of human development" activates a steady "legal gnosis" in the national legal thinking (Yakovenko I.G. \& Muzykantskiy A.I., 2011).

Within the last the entire national pravokulturnaya tradition marked unambiguously negative, and its creative potential and independence is being questioned. Some authors do not stop writing that an independent state and legal development of the Russian society, without "external" pravokulturnyh ideals and models (primarily Western), itself a deadlock motion vector, and the final "arrival station" - civilization authoritarianism (Gavrov S.N. 2004).

Other authors point to a "virtual" or "imitation" nature of legal development, arguing that, for example, the Russian constitutionalism - a "major political illusion" that the state of law - a kind of simulacrum bodriyarovsky that the development of legal awareness and legal culture of modern Russia - it is a fiction, and the mode of the rule of law - is "legally imaginary" and so on. (Pastukhov V.B., 2013). Such a steady negative trend analysis of the Russian legal system eliminates any human activity, social power in general suppress the national will, etc. This feeling of inferiority and hopelessness leaves only one term - vigorously go after development (in legal and political terms) civilizations, recreate and enter their state-legal tradition, losing its face and independently.

It seems that we need a paradigmatic approach and methodological perspective studies how the political evolution of Russia's legal system and the prospects for its transformation in accordance with the challenges of the time. Research strategies aimed at the knowledge of the national independence and the integrity of the political and legal organization of society (in the unity of its temporal and spatial development) can be designated as pravokulturnuyu. The term "pravokulturny" is used here in a narrow logical and conceptual sense, namely as part of the overall system - cultural integrity associated with the formation of the legal thinking activity and socio-cultural identity of a public law interaction in the system "personality-society - the right-state". 


\section{Literature Review}

In this research practice can be divided into four conceptual tradition of political and legal analysis of the government. First, a group of researchers who analyze the political phenomenon of the structural-functional terms, those should be attributed to the work of authors such as Almond G., Deutsch K., Durkheim D., Easton G., Kelsen K., Marx R., Merton T., Parsons, Sorokin, and others. (Merton R.K, 1957; Parsons T., 1954; Kelsen G., 1925 \& Sorokin, 1992).

Secondly, it is a conceptual version focuses on the institutional and regulatory treatment of the government, from the pen of foreign and domestic authors like Hannah Arendt, Baytin M.I., Homer I.N., Malii A.F., North D., John. Wallis, Chirkin V.E. et al. (Arendt, 1996; Baytin M.I., 2001; North, D., Wallis D. \& Weingast B., 2011).

Third, it is the political, sociological and And political doctrine, are guided by the understanding of state authority as a specific system of public power relations. This approach to the interpretation of this political phenomenon is represented in the works of Alekseeva N.N., Blau P., Luhmann N., Maltsev G., Mamut L.S., Podoroga V.A., Chirkin V.E. and Jünger E. et al. (Luhmann N., 2001; Mamut L.S., 1996 \& Chirkin V.E., 1996)

In the tradition of the fourth state authority is seen as a particular type of political rationality (Agamben G., 2001; Bourdieu P., 1993; Crouch K., 2010 \& Foucault M., 1999; et al.), Or as a social and psychological setting (Jouvenel B., 2011; Korkunov M.N., 2003 \& Petrazhitsky L.I., 2010; et al.), or as a mass political image (real or virtual) representations, archetypal installation, etc. (Isaev I.A., 2003; Ovchinnikov A.I., Mamychev A.Yu. \& Mamycheva D.I., 2015; et al.), Organizing social and political actors thinking activity and the process of institutionalization of public space overbearing.

\section{Methods and Materials}

The challenges of our time, different researchers described, cause today is not only the need for a comprehensive, intensive and adequate (socio-cultural) development and complication of the general theory of state power, but also, more importantly, the general concept of public authorities in modern society. Note that the methodological principle of this work stands the proposition that ignoring the political traditions and socio-cultural development trends leads to the fact that the conceptualization of state power often focuses on general, universalist model, and study public-government institutions with their historical (national and provintsionalnymi ) features occur on a pre-existing schemes, "renouncing" of all atypical, specific. Hence, quite often there are discrepancies, the theoretical confusion, ignoring factors and dominant in the political organization of society that have a significant and sometimes decisive influence on the institutional power configuration, the development of the political process, formal and informal interaction in the system "person - society - state".

The theoretical-methodological and practical terms, the work is based on the provisions of the new institutionalism, developed in the works of authors such as DiMaggio P.G., March J., Norton J., George Olson, Taylor R., Wallace J. Tabor A., Hull P. and Duvernet Aymar F. et al. (Armagan S. \& Portugal Ferreira M., 2005; Hall P.A. \& Taylor R., 1996; March J.G. \& Olsen J.P., 1984 \& Tyler T.R., 1994) in which policy institutions interpreted widely, on one hand, as a formal rule normative models, procedures and standards; and on the other as symbolic systems, cognitive scripts, socio-cultural and spiritual-moral patterns, organizes and manages the mental activity of people. This approach is most justified to adequately describe the state power as the institutional and regulatory, social and cultural phenomenon.

A study of state power based on the theoretical and methodological work: Averyanov V.V., Akhiezer A.S., Glebova I.I., Demetradze M.R. Dugin A.G., Lapin N.I. Lurie S.V., Mordovtsev A.Y. and Brewers Y.S. et al., Justifying fundamental relationship between political and socio-cultural dynamics of the process (Averyanov V., 2012; Demetradze M.R., 2012; Lurie S.V., 1994 \& Pivovarov Yu, 2006). Methodological and theoretical and practical experience of these authors made the basis of investigation of the influence of archetypal structures (socio-cultural codes), spiritual and moral, territorial, ethno-cultural and other factors and the evolution of the dominant system of state power, the ratio of traditional and modernizing transformation of political processes, and so on.

As a hypothesis we can formulate the following position: pravokulturnye study appears concretization of civilized approach to the law aimed at socio-cultural understanding of the law, various legal effects and state-legal processes, becoming, developing and reproducing in a certain succession of national and cultural integrity.

\section{Results and Discussion}

Socio-cultural aspect of political and legal studies allow, on the one hand, to analyze the evolution of the legal and political systems as a holistic socio-cultural (civilizational type and shape) of the phenomenon, despite the various twists and turns (random, evolutionary leaps, etc.) in its development; on the other - level (or at least minimize) "research costs" 
arising from the implementation of the strategy of civilization knowledge of law and state.

Last usually due to two factors. Firstly, a number of analysts directly (consciously) or indirectly reduce the civilizational approach to the state, law, policy to identify criteria and qualitative characteristics of the civilization of the political and legal system. In this context, public-legal space, discarding all the nuances in the interpretation and typology, differentiated into civilized (modern, developed, etc.) and civilized (backward, traditional, underdeveloped). However, the main theoretical and methodological position in this context are the central allocation, advanced civilizations legal projecting a model, an ideal of modernity and those spaces that only "entered the road of civilized development".

Obviously, there are the fundamental issues of modernization (and what is modernization - direct or indirect, complete and fragmentary, power or organic - the question is secondary) and convergence (mixing processes, unification, liberalization and the like) with the central, developed political and legal systems (Mordovtsev A.Yu., Mordovceva T.V., Mamychev A.Yu., 2015). As a consequence, the process of reconstruction of specific (socio-cultural) characteristics of law and state legal process, the selection of legal traditions, values, symbols and images are analyzed from the point of view of obstacles, barriers and so on. in the way of "civilization of perfection." However, in this area it is rarely a question of the limits of modernization and convergence in terms of preservation and reproduction pravokulturnoy integrity of society, as various legal "injection", "vaccination", "novel", etc. may eventually weaken the immune system of a living organism and destroy the unity of the political and legal life of society, give rise to the legal effects of defragmentation, political anomie, Dysnomia, the strain of justice, etc.

Secondly, it is a technocratic civilization unique interpretation aimed at the selection of organizational and legal, institutional and practical (various public law practice interaction in the system "person - society - the right - state") the right elements of society, without due attention to the fact that is the content of this uniqueness. It is true in this respect notes V.V. Averyanov, who believes that "a civilization without the tradition appears as a well-functioning infrastructure machine control system, but without controlling it (which, in fact, indicates the direction of German criticism of the phenomenon of "civilization"). In the compound of tradition and civilization in a single complex has grasp the essence of the real social systems. This category highlights ("tradition-civilization" or "tradition-system" - Ed.) Historical and typological unity of traditions and all the complex (traditional and non-traditional) events, of which there is a child of her civilization "(Averyanov V.V., 2012, p. 103). To paraphrase a researcher, we note that the current traditional pravokulturnaya coordinate system serves no particular way of political and legal systems and national legal and political culture, as the essential basis of which is its specific growing.

Consequently, "pravokulturnaya axis" appears as the content and the legal and political system (as civilizational phenomena) are a form of political and legal life of society, ie, the first is regarded as essential, qualitative characteristics of state-legal organization, and the second is analyzed as an external, specific - specific historical, systemic, organizational, legal, institutional, and so on. - Registration pravokulturnogo content. At the same time as registration of adequacy or inadequacy is already problematic instrumental value, ie, dominant concrete historical values and legal representation, legal institutions and agencies aimed at the reproduction of society pravokulturnoy integrity, unity and stability of the social system of its evolutionary development, maintaining the stability and harmony of the entire system of social and regulatory.

In this respect any institution (legal, political, religious), acting in a socio-cultural space can not be free from the environment in which it operates and sells a particular socially significant function. Otherwise, for example, if any institution establishes rules of conduct, which runs counter to the national legal and political thinking activity, it loses not only its effectiveness, but the social legitimacy.

Thus, the right section of the cultural transformation of the state-legal organization of society, in which the interaction of both modernization (innovation, inokulturnye, etc.), and conservative legal (traditional, customary law, etc.) elements provide harmonious and sustainable development of the entire system of social and regulatory framework in which the inclusion in the right section tradition of the various elements and complexes formed in a civilized environment, designed to strengthen and enhance the quality and integrity of the national political and legal life of society.

Thus, under the anthropological and socio-cultural areas of human cognition is considered an established position that each public-legal organization of a certain cultural integrity, continuity with their technologies, mechanisms of identification, spiritual and moral sovereignty, core (national and cultural) evolution of the project, representing primarily formative essence, "absorbent" and organizing the actual content of a particular era (various phenomena, processes, randomness in the institutional and socio-practical development of the social system), socio-psychological, cognitive and emotional canons (codes, standards, predpravovye codes of conduct, etc.), public legal person interaction in the system society - state and so on.

Therefore, from our point of view it is necessary to develop scientific directions, which involves a comprehensive analysis of the state power as pravokulturnogo phenomenon consists of three main sections: 1) the theory of government 
(or political encyclopedia of state power); 2); ideological and conceptual (doctrinal) basis for the development of the system of state power; 3 ) institutional and normative theory of organization and functioning of the government. Of course, the fact that the phenomenon of state power is also tied to a specific time and geopolitical geoyuridicheskomu continuum, in which the latter gets his existential status in the six interrelated projections:

- firstly, in the norms and values (axiological), reflecting the socio-cultural aspects influencing ideological and theoretical, doctrinal, ideological and conceptual-semantic perception, understanding and interpretation of the essence, social role and significance of the government, determines its stability and legitimacy;

- secondly, the structural-functional, in this context, the state power is associated with a stable system of public power institutions, its structural and functional characteristics, public relations and hidden patterns and relationships in the exercise of public authority, as well as with questions of optimality, the adequacy and effectiveness its functioning, regulation of public relations, promote the interests and needs of the dominant system "person - society - state", the resolution of conflicts and contradictions;

- third, in the institutional and normative, here state authority is seen as a system of legal powers that constitute the public power exercised by law in order to achieve certain goals;

- fourth, in the instrumental technology, according to which the state authority is analyzed as a system of organizational, material and symbolic resources needed to implement the administrative apparatus of the functional goals and objectives, as a special subject of politics involved in the accumulation, exchange and implementation of the above resources;

Fifth, in the sociological, in this aspect of the system of state authority is considered, on the one hand, as an interrelated set of specific political practices aimed at the implementation of the public power in society, and on the other is interpreted in terms of the adequacy of the latest social structures and cultural contexts, as well as the possibility of implementing socially oriented legal policy, administrative decisions, taking into account national and cultural features;

Sixth, in the geopolitical, the government is seen as a sovereign political organization in a certain area, which has supremacy, unity and socio-political integrity.

Given the knowledge of selected elements of state power as a socio-political and public legal phenomenon can formulate a working definition of the latter. At the same time, we emphasize that the state power as a complex phenomenon pravokulturny serves a specific type (link) of the total system of public authority, which implements the various political actors (political parties and movements, public organizations and movements, trade unions, etc.) and other institutions of civil society (eg, government institutions of local government), which has a rigid adherence to the socio-cultural and territorial space. In addition, public authorities, as noted above, is always realized within the strict legal forms, modes and procedures, and provides for the possibility of power forms of coercion, which is one of the fundamental differences between this type of public authority. To understand the functioning of the government in a modern state-steam process, the basic forms and modes of ruling the state and prospects of development of this phenomenon is the institutional and regulatory measure also seems impossible.

Thus, the government, in our view, should be treated as a system of officially recognized (legitimate and legal) government practices, procedures and institutions operating on the basis of socio-culturally conditioned ideas, images, symbols in a certain politically and territorially organized space, characterized by a sovereign, functionality and stability. In this respect, any state authority territorially sovereign, national and it is sustainable.

We note here that the monopoly of the government on the use of legal and legitimate violence (coercion) is, of course, a key feature of the government, however, recent studies devoted to the problems of the power aspect of violence (coercion) gradually "pushed" from the characteristics of the phenomenon. For example, the famous political philosopher A. Kojeve in his phenomenological analysis of power relations formulated three very important points for the understanding of the public authorities. Firstly, it proves that a legitimate "use of power is not only not the same as the use of force (violence), these two phenomena are mutually exclusive. Generally speaking, the use of the authorities should do nothing. The duty to intervene by force (violence) indicates that there is no power" (Kojeve A., 2006). This statement largely reflects not so much potential, authoritative understanding of power as a social and psychological its recognition, as well as the existing order, stability of power relations in society, eliminating backlash (explicit and latent nature), power relations (domination - subordination) and etc.

Further, we note that the activities government implements a different public (public) values, interests and needs with the common political order, and according to them carries out its functions and guides the development of the political and legal system, certain political institutions, both formal and informal institutions of civil society. All six dimensions outlined above are interrelated and mutually conditioning, formed not spontaneously, but developed on defined-lennom national historical foundation, and have a special, peculiar style of a particular society publicly-imperious 
thinking. All this formiruet unique flavor public life, the vector of its development, which not only allows administrative elite, but also to society its state-legal identity and integrity of life.

\section{Conclusion}

Today, there are three research strategies of knowledge of state power: the formation of an integrated and self-direction the general theory of state power; a separate section of political science, considering the state power as a kind of political power; section of the general theory of the state, analyzing the latest as institutional and regulatory framework. The most adequate is a comprehensive review of the latter as a complex socio-political and pravokulturnoy system, which politically is presented in an officially recognized (legitimate and legal) government practices, socio-political processes and technologies, public-legal institutions, acting on the basis of socio-culturally conditioned ideas, images, characters in a certain politically and territorially organized space.

At the present time we need to develop scientific field, which involves a comprehensive analysis of the state power as pravokulturnogo phenomenon consists of three main sections: 1 ) the theory of government (or political encyclopedia of state authority); 2); ideological and conceptual (doctrinal) basis for the development of the system of state power; 3 ) institutional and normative theory of organization and functioning of the government.

State power in specific historical and socio-political conditions should be reviewed in six interrelated dimensions: value-normative, structural-functional, institutional and normative, instrumental, technological, sociological and geopolitical. All selected and analyzed in the six dimensions are interrelated and mutually conditioning, formed not spontaneously and successively developed to a certain national cultural foundation, and a special form (civilization) style of thinking activity of public power.

\section{References}

Averyanov, V.V. (2012) Tradition and the dynamic of conservatism. M.

Agamben, D. (2001) Homo sacer. Sovereign power and bare life. M.

Arendt, H. (1996) The Origins of Totalitarianism. M.

Baytin, M.I. (2001) The essence of the law: Modern normativistskoe legal thinking on the verge of two centuries. Saratov: SGAP.

Bourdieu, P. (1993) Sociology of Politics. M.

Gavrov, S.N. (2004) in the name of modernization of empire. Social and cultural aspects of modernization processes in Russia. M.

Demetradze, M.R. (2012) The central zone of the traditional socio-cultural values as an information-communicative phenomenon. New approaches to the study of tradition and traditionalism (for example, Russia). M.

De Jouvenel, B. (2011) Power: The natural history of its growth. M.

Isaev, I.A. (2003) Politica hermetica: hidden aspects of power. M.

Kelsen, G. (1925) General theory of the state. Berlin: Ed. Springer

Kojeve, A. (2006) The concept of power. M.

Korkunov, N.M (2003) Lectures on the general theory of law. St. Petersburg.

Crouch, K. (2010) post-democracy. M.

Luhmann, N. (2001) Power. M.

Lurie, S.V. (1994) Metamorphoses traditional consciousness. Experience in the development of theoretical bases of ethnic psychology and its application to the analysis of historical and ethnographic material. St. Petersburg.

Mamut, L.S. (1996) Metamorphoses State // Problems of perception value approach in law: tradition and renewal. M.

North, D., Wallis D. \& B. Weingast (2011) Violence and social orders. The conceptual framework for the interpretation of the written history of mankind. M.

Pastukhov, V.B. (2013) have a constitutional features ... Challenges and Answers Russian constitutionalism // Polis. Number 1.

Petrazhitsky, L.I. (2010) The Theory and Politics of Law. St. Petersburg.

Pivovarov, Yu.S. (2006) Russian political tradition and modernity. M.

Sorokin, P. (1992), Man. Civilization. Society. M.

Fouco, M. (1999) Discipline and Punish. Birth of the Prison. M.

Chirkin, V.E. Fundamentals of of state authority. M., 1996

Yakovenko, I.G. \& Muzykantskiy A.I. (2011) Manichaeism and Gnosticism: the cultural codes of Russian civilization. M.

Armagan S., Portugal Ferreira M. (2005) The Impact of Political Culture on Firms' Choice of Exploitation-Exploratio Internalization Strategy // International Journal of Cross Cultural Management. - London, SAGE. Vol 5 (3)

Hall P.A., Taylor R. (1996) Political Science and Three new institutionalism // Political studies. Vol. 44.

March J.G., Olsen J.P. (1984) The new institutionalism: Organizational factors in political life // American political science review. Wash., D.C. Vol. 78. No 3

Merton R.K. (1957) Social Theory and Social Structure / Robert K. Merton. Enl. Ed. New York: Free press 
Mordovtsev A.Yu., Mordovceva T.V., Mamychev A.Yu. (2015) Convergence of law: the variety of discourses // Mediterranean Journal of Social Sciences. Vol. 6, № 3,.

Ovchinnikov A.I., Mamychev A.Yu., Mamycheva D.I. (2015) Socio-cultural foundations of coding state-legal development // Mediterranean Journal of Social Sciences. Vol. 6. №3.

Parsons T. (1954) Essays in sociological theory. Glencoe, 1954.

Tyler T.R. (1994) Governing and diversity: The effect of fair decisionmaking procedures on legitimacy of government // Law and society review. - Beverly Hills, Calif.,Vol. 28, No 4 